і перспективи: Збірник НПУ імені М. П. Драгоманова. - 2007. - Вип. 7. - С. 150-156. 6. Тришина С. В. Информационная компетентность как педагогическая категория [Электронный ресурс] / С.В. Тришина // Интернет-журнал «Эйдос». - 2005. - Режим доступа : http://www.eidos.ru/journal/2005/0910-11.htm. 8. Ягупов В. В. Педагогіка : [навч. посіб.] / В. В. Ягупов. К. : Либідь, 2003. - 560 с.

УДК 371.10. 145

Л. Ю. Москальова, доктор пед. наук, професор, Науково-дослідний інститут духовного розвитку людини Східноукраїнського начіонального університету імені Володимира Даля, Мелітопольський державний педагогічний університет імені Богдана Хмельницького

\title{
ПІДГОТОВКА МАЙБУТНІХ УЧИТЕЛІВ ЗА СПЕЦАЛІЗАЦІЄЮ «ХРИСТИЯНСЬКА ЕТИКА»
}

Москальова Л. Ю. Підготовка майбутніх учителів за спеціалізацією «Християнська етика».

У статті розкрито компетенції в підготовці майбутніх учителів християнської етики, представлено сутність основних вимог до викладачів, які мають забезпечити навчально-виховний процес у цьому напрямі.

Ключові слова: майбутні вчителі, компетенція, християнська етика.

Москалева Л. Ю. Подготовка будущих учителей по специализации «Христианская этика».

В статье раскрыты компетенции в подготовке будущих учителей христианской этики, представлена сущность основных требований к преподавателям, которые должны обеспечить учебно-воспитательный процесс в этом направлении.

Ключевые слова: будущие учителя, компетенция, христианская этика.

Moskalyova L. Y. The training of future teachers with specialization «The Christian ethics».

In the article the competence in the preparation of future teachers of Christian ethics, represented the essence of the main requirements for teachers, which should provide the educational process in this direction.

Key words: future teacher competence, the Christian ethic.

Проблема якості підготовки педагогів за спеціалізацією «Християнська етика» в умовах реформування освітньої системи Української держави набуває особливої актуальності. У запорізькому регіоні $\epsilon$ позитивні зрушення в цьому напрямку. Зокрема, у школах за рахунок варіативної компоненти виділяються години для впровадження курсів духовноморального спрямування. Проте питання якості підготовки педагогів 3 цього напряму залишається відкритим. Звісно, наявні курси підвищення кваліфікації, але відповідної світовому рівню, якісної, базової освіти з «Християнської етики» та кваліфікації вчителі у Запорізькому регіоні нині ще не отримують.

Meта статmi: з'ясувати основні компетенції у спеціалізації «Християнська етика» для підготовки майбутніх учителів.

Проблематика впливу духовно-моральних цінностей у підготовці сучасної молоді вивчається провідними науковцями на теренах пострадянського суспільства. Це роботи українських науковців - I. Беха, Г. Васяновича, І. Зязюна, В. Жуковського, В. Молодиченка, Л. Хоружої, Г. Шевченко та ін. Також можемо навести i авторів сучасних дисертаційних праць, де християнська етика подана як окремий напрям духовного життя (М. Махортова [1], I. Кулікова [2], І. Столяров [3] та ін.).

На сьогодні у Мелітопольському державному педагогічному університеті імені Богдана Хмельницького розпочалася підготовка майбутніх спеціалістів за педагогічним напрямом (0101) зі спеціальності «Початкова освіта» у поєднанні зі спеціалізацією «Християнська етика». У попередньо розробленому варіативному стандарті для спеціалізації «Християнська етика» передбачено формування в таких спеціалістів компетенцій для 
виконання особливих завдань у майбутній професійній діяльності. Ці компетенції, згідно із розробленим стандартом, поділяються на кілька груп, а саме: соціально-особистісні, загальнонаукові, інструментальні, морально-етичні, загальнопрофесійні, спеціалізованопрофесійні. Схарактеризуємо ці компетенції більш докладно.

Так, група соціально-особистісних компетенцій передбачає: розуміння і сприйняття норм християнської етики та правил моральної поведінки відносно інших людей, природного оточення (принципи біоетики); розуміння і пропагування норм здорового способу життя, визнання необхідності їх дотримання упродовж життя; знання і розуміння етичних закономірностей, що є прийнятними в суспільстві, визнання необхідності їх дотримання впродовж усього життя та подальшого вдосконалення; розуміння необхідності підвищення рівня освіти та власного духовно-морального розвитку впродовж усього життя; знання і розуміння необхідності критичних зауважень для подальшого розвитку i саморозвитку, здатність до конструктивної самокритики, самооцінки, презентації набутого досвіду та отриманих результатів; знання та розуміння основних підходів, принципів, мети, методів творчої діяльності, здатність до системного мислення у досягненні професійних результатів; знання закономірностей, форм і методів міжособистісного спілкування, визнання необхідності у повазі до інших людей, у сприйнятті та розумінні багатства i різноманітності культур у всьому світі, поліконфесійності українського суспільства, адаптивності до умов співжиття 3 іншими людьми, розуміння відмінностей між системами цінностей різних релігійних або етнічних груп; визнання необхідності в активній, наполегливій діяльності, що спрямована на досягнення мети та виконання прийнятих рішень для якісного виконання професійних обов'язків тощо.

Наступна група компетенцій, що має бути сформована у майбутніх вчителів християнської етики, включає загально-наукові компетенції, серед яких можна визначити такі: базові знання основ теології, релігієзнавства, християнської філософії і педагогіки, психології, що сприяють розвитку духовно-моральної культури особистості, спрямовують iii до набуття морально-етичних цінностей; знання християнської етики, розуміння причинно-наслідкових зв'язків духовно-морального розвитку особистості у соціальному середовищі суспільства й уміння їх використовувати у професійній і соціально-виховній діяльності; знання фундаментальних розділів християнської педагогіки, біблейської історії, історії української християнської культури, в обсязі, необхідному для володіння методичним апаратом під час викладання основ християнської етики та курсів духовноморального спрямування, здатність здійснювати виховні впливи на особистість; базові знання 3 педагогічної, психологічної науки, необхідних для засвоєння загальнопрофесійних дисциплін та спецкурсів духовно-морального спрямування тощо.

Інструментальні компетенції у підготовці майбутніх вчителів християнської етики, на нашу думку, повинні мати такі складники: здатність до ефективної комунікації, знання письмової й усної державної та рідної мови, здатність читати і розуміти різні тексти морально-етичної тематики, розуміння стратегій етичних текстів, їх мети для виховання та освіти; знання законів, методів та правил управління інформаційними потоками у роботі із дітьми та учнівською молоддю, під час роботи із документацією, здатність переконливо формулювати аргументи і повною мірою враховувати інші позиції, що виражаються в різних формах (письмово або усно); знання методів та правил роботи з комп'ютером та роботи в Інтернеті (спілкування в режимі он-лайн, листування в соціальних мережах), знання про можливість пошуку, збору та оброблення інформації, наукових даних, різних етичних концепцій для їх використання у дослідженнях, знання методів організації етичних знань 3 урахуванням ціннісно-генерувального підходу; знання законів, технологій, методів проведення науково-педагогічних досліджень тощо.

Центральною групою у підготовці майбутніх вчителів християнської етики, на нашу думку, є морально-етичні компетенції. Серед них: здатність до адекватної оцінки власних моральних почуттів та вчинків, знання і розуміння законів етичного спілкування; здатність 
до морального судження, вміння застосувати етичні знання, розрізняти добро і зло, регулювати моральну поведінку, підвищувати здатність до морального резонансу, удосконалення форм і манер поведінки під час міжособистісного спілкування; знання етичних стратегій, здатність побудувати власну стратегію у професійній та соціальновиховній діяльності, що передбачає активний рух до здійснення моральних вчинків; здатність та вміння розрізняти елітарну і масову культуру, відзначати іiі особливості, емоційну піднесеність моральних почуттів тощо.

Загальнопрофесійні компетенції, на нашу думку, мають включати: базові уявлення у майбутніх учителів християнської етики про методологію педагогічних досліджень, методик та технологій дослідження й аналізу актуальних соціально-педагогічних проблем, розуміння складності соціально-психологічних утворень суб'єктів виховного впливу, їх різноманіття, здатність до взаємодії в сучасних соціально-економічних умовах для розв'язання виховних завдань та запобігання кризових явищ у навчально-виховному процесі; знання методів формування світогляду дітей та учнівської молоді, розроблення обгрунтованих алгоритмів та технологій у виховному процесі, функціонування різних соціальних систем та інститутів; здатність застосовувати сучасні експериментальні методи соціально-педагогічної роботи з суб'єктами виховного впливу на заняттях та позанавчальний час, знання i володіння системою моральних вчинків; знання педагогічних методів, засобів планування і проектування виховних справ і програм, динаміки розвитку рівня вихованості дітей та учнівської молоді; базові уявлення про моральність християнських цінностей як загальнолюдських, їхніх переваг для розв'язання конкретних виховних завдань, методів розроблення організаційно-педагогічного забезпечення виховних систем 3 використанням інноваційних і традиційних технологій соціально-виховної роботи; знання базових принципів організації та функціонування технічних засобів навчання, їх можливостей і застосуванню під час викладання курсів духовно-морального спрямування, проведення дозвіллєвих заходів, проектування виховних справ; знання основних підходів та методів щодо організації, планування, керування та контролю в роботі з проектування, проведення, корекції та педагогічного супроводу виховних програм і справ тощо.

Група спеціалізовано-професійних компетенцій, які має набути майбутні вчителі християнської етики, розкривається через такі їі складники: знання та розуміння методів викладання християнської етики, здатність співвідносити моральні дії та вчинки дітей та учнів із вимогами оточення, простежити взаємозв'язок власної моральної діяльності із професійними обов'язками; знання методів активного виховного впливу на дітей та учнівську молодь, здатність вносити якісні зміни у життя вихованців, методів навіювання, переконання для побудови виховного процесу та дослідження різних моделей поведінки, акцентуацій, здатність до прогнозування розвитку різних подій для кожного типу особистості та моделей оптимізації, раціоналізації, оптимального керування та прийняття моральних рішень; здатність до етичних суджень, оцінки, володіння етичними знаннями, уміннями розрізняти позитивні та негативні ознаки явищ, побачити прояви добра і зла, сформованість відповідального ставлення до формування моральної свідомості, почуттів і поведінки дітей та учнівської молоді; знання методів розроблення та дослідження алгоритмів розв'язування моральних задач, моделювання прийняття морально-етичних рішень, здатності до виявлення співпереживання, співчуття в навчально-комунікативній діяльності, виявлення активності в допомозі в опрацюванні навчального матеріалу 3 християнської етики, орієнтації на позитивне прийняття дій та моральних вчинків іншої людини; знання наявних морально-етичних проблем соціального середовища, у якому перебувають діти й учні, здатність до визначення морально-етичних проблем, на які натрапляє вихованець, до спрямування зусиль на їх розв'язання; знання та розуміння цінностей педагогічної професії, сукупності етичних стандартів, що регулюють моральну поведінку й активність педагога у професійній діяльності; здатність знаходити безпосередні вияви через нові культурні форми у виховній роботі; знання концепцій 
християнської культури, етичних поглядів в суспільстві, здатність орієнтувати дітей та учнівську молодь на результати моральної діяльності; здатність етично мислити, готовність до активної виховної діяльності із дітьми та учнівською молоддю; спроможність до вияву почуття глибокої сердечної прихильності до оточення; знання законів співіснування у соціумі, класифікації моральних явищ, принципів діагностики та побудови виховного процесу із врахуванням діагностичних даних, здатність до розроблення авторських методик викладання християнської етики, підтримки та адаптації інноваційних виховних методик, здатність викликати позитивні зміни в поведінці дітей та учнівської молоді; знання способів доведення інформації морально-етичного характеру до дитячої та учнівської аудиторії; прийомів активізації розвитку етичного мислення через емоційну сферу; знання соціально-психологічних законів доброзичливого спілкування між учасниками навчально-виховного процесу; здатність до проведення корекційної роботи щодо формуванню моральних якостей; знання християнської символіки, різних типів етичних текстів у християнській літературі (проповіді, казки, оповідання, притчі тощо), сакральної музики, іконопису та архітектури, їх основні функції у роботі із дітьми та учнівською молоддю тощо.

Підкреслимо, що ці компетенції формуються на лекційних та семінарських заняттях, а також на тренінгових заняттях, які об'єднані в комплекс. Додамо, що обов'язковою вимогою до процесу викладання навчальних дисциплін нормативної частини змісту навчання $є$ участь докторів наук, професорів, кандидатів наук, доцентів, які мають певний стаж практичної, наукової та педагогічної роботи. Доцільно, щоб викладачі, які забезпечують дисципліни циклу професійної та практичної підготовки, переважно мали наукові ступені в галузі філософських, психологічних, педагогічних або богословських наук. Також вважаємо доцільним, щоб викладачі, які забезпечують викладання дисциплін духовно-морального спрямування, проходили стажування у провідних українських та зарубіжних організаціях, що спеціалізуються у богословському, філософському, психолого-педагогічному напрямі.

Отже, якісна підготовка майбутніх учителів зі спеціалізації «Християнська етика» має велике значення у навчально-виховного процесі демократичного суспільства. Перспективою досліджень $є$ розроблення навчальних посібників, конспектів лекцій та методичних вказівок щодо вивчення навчальних дисциплін духовно-морального спрямування.

\section{Література}

1. Махортова М. В. Духовно-нравственное воспитание личности на основе православной этики: Социально-философский аналіз : дис. ... канд. филос. наук: 09.00.11 «Социальная философия» / Махортова Марина Владимировна. - Ставрополь : Северокавк. гос. техн. ун-т, 2000. - 174 с. 2. Куликова И. Я. История христианской музыки как компонент целостной музыкальноисторической подготовки студентов педагогического вуза : дис. ... канд. пед. наук: 13.00 .02 «Теория и методика обучения и воспитания» / Куликова Ирина Яковлевна. - М. : МГОПУ им. М. А. Шолохова, 2004. - 167 с. З. Столяров И. Н. Место и роль христианской этики в формировании духовно-ценностных ориентаций молодежи : дис. ... канд. филос. наук: 22.00 .06 «Социология духовной жизни» / Столяров Игорь Николаевич. - М. : МПГУ, 1996. - 169 с. 